ISSN 0258-7122

Bangladesh J. Agril. Res. 35(1) : 83-93, March 2010

\title{
ECONOMICS OF HYBRID MAIZE PRODUCTION IN SOME SELECTED AREAS OF BANGLADESH
}

\author{
M. R. KARIM ${ }^{1}$, MONIRUZZAMAN ${ }^{2}$ AND Q. M. ALAM ${ }^{3}$
}

\begin{abstract}
The present study is an attempt to assess the existing agronomic practices of hybrid maize cultivation, its profitability, constraints, and factors affecting hybrid maize production. The majority of the total farmers sowed seeds during the first week of December. The average seed rate was found to be $20.94 \mathrm{~kg}$ per hectare. About 16 varieties were found to cultivate by farmers, of which majority farmers used NK-40 followed by Pacific-II. All kinds of fertilizer used by the farmers were below the optimum level of recommendation. About 33 and 28 percent of the total variable cost was for human labour and chemical fertilizer, respectively. The average yield of hybrid maize was found higher than the national average. The average gross margin was observed to be Tk. 28456 on total variable cost basis. The cost per kilogram of maize cultivation was Tk. 4.12 and return from one kilogram of maize production was Tk. 7.80. It is found that the coefficient of human labour, land preparation, irrigation, urea and borax have significantly impact on gross return. Timely non-availability of seeds, high price of fertilizer, and low price of yield were the major problems for hybrid maize production. Farmers cultivated hybrid maize because of higher yield, higher income, and easy growing.
\end{abstract}

Keywords: Gross return, gross margin, and profitability.

\section{Introduction}

The crop maize is gaining popularity in the country very quickly due to its high yield potential. Maize acreage and production have an increasing tendency with the introduction of hybrid since 1993. Area, production, and yield of maize have increased by $17 \%, 33 \%$, and $16 \%$, respectively, which reflect the effect of adopting improved technology (Mohiuddin, 2003). The area, production, and yield of wheat and maize from 1999-2000 to 2005-06 are presented in Table 1. It is revealed from the Table that area, production, and yield of wheat are decreasing in each year from 1999-00 to 2005-06, while it is increasing for maize in each year during the same period. Its position is $1^{\text {st }}$ among the cereals in terms of yield, but in terms of area and production, it ranks $3^{\text {rd }}$ just after rice and wheat (BBS, 2003, 2006). Because of more nutritious status, it could be good source of nutrients for under nourished and mal-nourished population in Bangladesh. It is

${ }^{1}$ Principal Scientific Officer, Agricultural Economics Section, HRC, BARI, Gazipur 1701, ${ }^{2}$ Scientific Officer, Agricultural Economics Division, BARI, Gazipur 1701 and ${ }^{3}$ Chief Scientific Officer, Agricultural Economics Division, BARI, Gazipur 1701, Bangladesh. 
now widely used in the poultry farms and animal feeding, as well as people consume roasted and fried maize in Bangladesh.

Table 1. Area, production, and yield of wheat and maize over the period from 19992000 to 2005-2006.

\begin{tabular}{c|l|l|l|l|l|l}
\hline \multirow{2}{*}{ Year } & \multicolumn{3}{|c|}{ Wheat } & \multicolumn{3}{c}{ Maize } \\
\cline { 2 - 7 } & Area (ha) & $\begin{array}{c}\text { Production } \\
\text { (mt/ha) }\end{array}$ & Yield (ha) & Area (ha) & $\begin{array}{c}\text { Production } \\
\text { (mt/ha) }\end{array}$ & Yield (ha) \\
\hline $1999-00$ & 832000 & 1840000 & 2.21 & 3161 & 4075 & 1.29 \\
$2000-01$ & 772000 & 1673000 & 2.17 & 4901 & 10350 & 2.11 \\
$2001-02$ & 742000 & 1606000 & 2.16 & 19972 & 64335 & 3.22 \\
$2002-03$ & 706000 & 1507000 & 2.13 & 29059 & 117255 & 4.04 \\
$2003-04$ & 567000 & 1248000 & 2.20 & 50030 & 241460 & 4.83 \\
$2004-05$ & 558000 & 976000 & 1.75 & 66803 & 356280 & 5.33 \\
$2005-06$ & 481000 & 772000 & 1.60 & 98408 & 521525 & 5.30 \\
\hline
\end{tabular}

Source: BBS (2003, 2006)

The population growth in Bangladesh puts great pressure on the country's food production. As regard food, cereal is still staple one for Bangladeshi people. In terms of human consumption maize also occupies the third position after rice and wheat in the country (HIES, 2005).The country is importing a huge amount of maize with the increasing demand from poultry and other feed industries. Therefore, maize has gained an increasingly important attention by the government. At present, per year requirement of maize is about 12 lac mt. Now a days, there are many organizations who are working for increasing maize production in Bangladesh.

It is recognized that in order to expand the area of this crop as well as to fit this crop in the farmers cropping system, studies are needed to ascertain its cost and return situation in relation to profitability of input use and farmer's resource use efficiency. The present study was undertaken to provide information through fulfillment of a set of objectives given below:

\section{Objectives:}

The specific objectives were-

i. to identify the existing practices of maize cultivation;

ii. to assess the cost and returns from maize production;

iii. to study the interrelationship between inputs and outputs of maize;

iv. to find out the socio-economic constraints to its higher production at farm level. 


\section{Materials and Method}

The present study was conducted in four districts, namely Rangpur, Dinajpur, Bogra, and Kushtia. Extensive cultivation of maize was the major criteria for the selection of the study area. After selecting the districts, one Upazilla from each district and one Mouza from each Upazilla were selected randomly. Finally four mouzas (one from each union) were selected randomly for this study. So, the lists of maize growers from each Mouza were collected and finally a total of 120 farmers were selected randomly taking 30 from each Mouza. Data were collected through pre-designed and pre-tested interview schedules. The collected data were summarized and analyzed to fulfill the objectives set for the study. Tabular method of analysis using average, percentages, ratios, etc. was applied in this study. The production of hybrid maize is likely to be influenced by different factors. To determine the contribution of some important inputs of growing hybrid maize, the Cobb-Douglas production model was estimated because of the best fit of the sample data. The functional form of the Cobb-Douglas multiple regression equation was as follows:

$\mathrm{Y}=\mathrm{a} \mathrm{X}_{1}^{\mathrm{b}}{ }_{1} \mathrm{X}_{2}^{\mathrm{b}}{ }_{2} \ldots \ldots \ldots \ldots \ldots \ldots . . . \mathrm{X}_{10}{ }_{10}^{\mathrm{b}}+\mathrm{U}_{\mathrm{i}}$

For the purpose of the present empirical exercise, the Cobb-Douglas production function was converted into the following logarithmic (Double log) form with variables specific as under:

$\mathrm{L}_{\mathrm{n}} \mathrm{Y}=\operatorname{Ln} \mathrm{a}+\mathrm{b}_{\mathrm{i}} \operatorname{Ln} \mathrm{X}_{1}+\mathrm{b}_{2} \operatorname{Ln} \mathrm{X}_{2}+\mathrm{b}_{3} \operatorname{Ln} \mathrm{X}_{3}+\mathrm{b}_{4} \operatorname{Ln} \mathrm{X}_{4}+\mathrm{b}_{5} \operatorname{Ln} \mathrm{X}_{5}+\mathrm{b}_{6} \operatorname{Ln} \mathrm{X}_{6}+\mathrm{b}_{7}$ $\operatorname{Ln} \mathrm{X}_{7}+\mathrm{b}_{8} \operatorname{Ln} \mathrm{X}_{8}+\mathrm{b}_{9} \operatorname{Ln} \mathrm{X}_{9}+\mathrm{b}_{10} \operatorname{Ln} \mathrm{X}_{10}+\mathrm{U}_{\mathrm{i}}$

Where,

$\mathrm{Y}=$ Gross return $(\mathrm{Tk} / \mathrm{ha})$

$\mathrm{X}_{1}=$ Human labour (Tk/ha)

$\mathrm{X}_{2}=$ Land preparation cost (Tk/ha)

$\mathrm{X}_{3}=$ Irrigation cost $(\mathrm{Tk} / \mathrm{ha})$

$\mathrm{X}_{4}=$ Cost of TSP $(\mathrm{Tk} / \mathrm{ha})$

$\mathrm{X}_{5}=$ Cost of Urea (Tk/ha)

$\mathrm{X}_{6}=$ Cost of MP (Tk/ha)

$\mathrm{X}_{7}=$ Cost of Zinc (Tk/ha)

$\mathrm{X}_{8}=$ Cost of Gypsum $(\mathrm{Tk} / \mathrm{ha})$

$\mathrm{X}_{9}=$ Cost of Borax (Tk/ha)

$\mathrm{X}_{10}=$ Cost of manure $(\mathrm{Tk} / \mathrm{ha})$

$\mathrm{a}=$ Constant of intercept

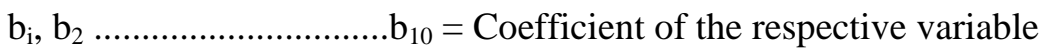

$\mathrm{U}_{\mathrm{i}}=$ Error term. 


\section{Results and Discussion}

\section{Level of technology employed in the production of hybrid maize}

For achieving higher yield and profitability, appropriate input use and time of operation is important. It is worthwhile to know the existing technology in terms of agronomic practices, time of each operation and input use in different locations. Existing technology of maize followed by the farmers from preparation of land for seed sowing to harvesting of crop are being presented below:

Land preparation: Land preparation for maize production included ploughing, laddering and other activities needed to make the soil suitable for sowing seeds. It is revealed that the number of ploughing varied from farm to farm and location to location. Ploughing on the survey plot started in the last week of September. In all areas, farmers ploughed their lands with the help of power tiller. It was observed that on the average, about $47 \%$ of the total farms used 4 times ploughing in the survey plot for land preparation followed by about 36\% with 5 times ploughings. Maximum number of farmers at Dinajpur and Kushtia were found to plough their lands 4 times, whereas the highest number of farmers in the remaining two districts ploughed the survey plot 5 times.

Sowing of seeds: Farmers followed line sowing method in planting maize seeds. Plantation of maize seed started from the last week of October and continued up to the first week of January. A perusal of Table 1 reveals that on the average, highest (37\%) percent of farmers sowed the seeds during the first week of December followed by 20 percent farmers during second week of December. In Kushtia, highest percent of farmers sowed seeds during third week of December.

Table 1. Distribution of farmers according to different dates of sowing.

\begin{tabular}{lllllllll}
\hline \multicolumn{1}{c}{ Date of sowing } & \multicolumn{5}{c}{ Percent of farmers } \\
\hline \multicolumn{1}{c}{ Month } & Week & Rangpur & Dinajpur & Bogra & Kushtia & All areas \\
\hline October & 4 & - & - & 3.33 & - & 0.83 \\
\hline November & 1 & - & - & 6.67 & - & 1.67 \\
& 3 & 3.33 & - & 6.67 & 13.33 & 5.83 \\
& 4 & 13.33 & 26.67 & 30.00 & 6.67 & 19.17 \\
\hline December & 1 & 56.67 & 50.00 & 36.67 & 3.33 & 36.67 \\
& 2 & 26.67 & 20.00 & 16.67 & 16.67 & 20.00 \\
& 3 & - & - & - & 36.67 & 9.17 \\
& 4 & - & 3.33 & - & 16.67 & 5.00 \\
\hline January & 1 & - & - & - & 6.67 & 1.67 \\
\hline Total & & 100 & 100 & 100 & 100 & 100 \\
\hline
\end{tabular}


Variety used: Maize varieties sowed by the farmers are presented in Table 2 . About 16 varieties were found to cultivate by the sample farmers. On the average, the highest (about 27\%) percent of farmers used NK-40 followed by Pacific-Il. Highest (33.33\%) percent of the sample farmers at Rangpur sowed NK-40. The variety Pacific-11 was found sowing by the highest percentage of (46.67\%) farmers in Kushtia. On the contrary, the variety 900M was used by the highest percent of the farmers at Dinajpur and Bogra. Other varities used by sample farmers included Indian hybrid maize varieties 740, 985, 980, 1437, and Heera 405. Main sources of seeds were Supreme Seed Company, Siddique Seed Company, Kushtia Seed Company, BADC, BRAC, etc.

The average seed rate per hectare of maize cultivation was found to be 20.94 $\mathrm{kg}$. The seed rate used by the farmers was almost similar to recommended seed rate. The seed rate per hectare was found higher in Bogra (about $23 \mathrm{~kg}$ ) compared to that in other three districts (Table 2). Recommended seed rate was $19-21 \mathrm{~kg} / \mathrm{ha}$.

Table-2. Variety used by the farmers.

\begin{tabular}{l|l|l|l|l|l}
\hline \multirow{2}{*}{ Variety } & \multicolumn{5}{c}{ Percent of the sample farmers } \\
\cline { 2 - 6 } & Rangpur & Dinajpur & \multicolumn{1}{c}{ Bogra } & Kushtia & All areas \\
\hline NK-40 & 33.33 & 26.67 & 23.33 & 23.33 & 26.67 \\
NK-46 & 16.67 & 10.00 & 6.67 & 26.67 & 15.00 \\
NK- 48 & 6.67 & - & - & - & 1.67 \\
NK-60 & 6.67 & - & - & - & 1.67 \\
Pacific-11 & 16.67 & - & 16.67 & 46.67 & 20.00 \\
Pacific-60 & 10.00 & 3.33 & 6.67 & - & 5.00 \\
900M & 3.33 & 33.33 & 26.67 & - & 15.83 \\
Kanok & - & 3.33 & 10.00 & - & 3.33 \\
717 & - & 13.33 & - & - & 3.33 \\
BARI-5 & 6.67 & - & - & - & 1.67 \\
827 & - & 6.67 & - & - & 1.67 \\
Others & - & 3.33 & 10.00 & 3.33 & 4.17 \\
\hline Total & 100 & 100 & 100 & 100 & 100 \\
Seed rate (kg/ha) & 20.22 & 20.37 & 22.65 & 20.52 & 20.94 \\
\hline
\end{tabular}

Variety-wise yield was also observed and presented in Table 3. It was observed that NK-40 performed better in comparison to other varieties sown in the survey plots. Among the varieties, $900 \mathrm{M}$ was in second position in terms of yield. The lowest yield was obtained by using the variety Pacific-II. 
Table 3. Variety-wise yield of hybrid maize.

\begin{tabular}{l|l|l|l}
\hline \multicolumn{1}{c|}{ Name of variety } & \multicolumn{1}{c|}{ No. of samples } & Percent of farmers & Yield (kg/ha) \\
\hline NK-40 & 32 & 26.67 & 7676 \\
NK-46 & 19 & 15.83 & 7258 \\
Pacific-Il & 24 & 20.00 & 6851 \\
900M & 20 & 16.67 & 7470 \\
BARI-5 & 2 & 1.67 & 7394 \\
Survey plot & 120 & 100 & 7330 \\
\hline
\end{tabular}

Use of manure and fertilizer: Use of inorganic and chemical fertilizer by the sample farmers varied from location to location. All farmers used urea, TSP, MP, and zinc for maize cultivation. It is visualized from Table 4 that the average dose of manure application was about $5460 \mathrm{~kg}$ per hectare. The application of manure per hectare was found much higher in Rangpur district. On an average, $484 \mathrm{~kg}$ urea, $214 \mathrm{~kg}$ TSP, $166 \mathrm{~kg}$ MP, and $6 \mathrm{~kg}$ zinc per hectare were applied in the cultivation of maize. Urea application was higher and manure application was lower at Kushtia. Among the different kinds of fertilizer used, the rate of application of urea was higher than those of other fertilizers. Gypsum and Borax application was not found in all the locations. The highest rate of TSP application was found in Dinajpur, whereas MP was found highest in Kushtia. It is visualized that the rate of fertilizer application by the sample farmers was below the level of recommended dose. All kinds of fertilizer used by the farmers were below the optimum level. Recommended doses of fertilizer application are as follows: Urea 500-580 kg/ha, TSP 260-300 kg/ha, MP 185-2 10 kg/ha, gypsum 210-235 kg/ha, Zn 12-15 kg/ha, borax 5-8 kg/ha and cowdung 4450-5000 kg/ha.

Table 4. Location-wise average level of input use by the sample farmers.

\begin{tabular}{|c|c|c|c|c|c|}
\hline \multirow{2}{*}{ Item } & \multicolumn{5}{|c|}{ Input used by the sample farmers $(\mathrm{kg} / \mathrm{ha})$} \\
\hline & Rangpur & Dinajpur & Bogra & Kushtia & All areas \\
\hline Cowdung & 7797 & 6211 & 5413 & 2418 & 5460 \\
\hline Urea & 419 & 372 & 505 & 638 & 484 \\
\hline TSP & 226 & 360 & 253 & 218 & 214 \\
\hline MP & 168 & 108 & 169 & 218 & 166 \\
\hline $\mathrm{Zn}$ & 7 & 7 & 5.02 & 4.65 & 6 \\
\hline Borax & 5 & 3 & - & - & 2 \\
\hline Gypsum & - & 79 & 86 & - & 41 \\
\hline \multicolumn{6}{|c|}{ Recommended doses (kg/ha) } \\
\hline Cowdung & - & - & - & - & $4450-5000$ \\
\hline Urea & - & - & - & - & $500-580$ \\
\hline TSP & - & - & - & - & $260-300$ \\
\hline MP & - & - & - & - & $185-210$ \\
\hline $\mathrm{Zn}$ & - & - & - & - & 210-235 \\
\hline Borax & - & - & - & - & $12-15$ \\
\hline Gypsum & - & - & - & - & 5-8 \\
\hline
\end{tabular}


Weeding: Weeding in maize field was found to be done in all the locations ranging from one to three times. Weeding was done manually by utilizing human labour. Number of the sample farmers according to number of weedings in the survey plot is also observed in this study. Highest about 44 percent of farmers performed weeding two times in their survey plots. It was found that the highest percent of sample farmers in Dinajpur, Rangpur, and Bogra performed two times weeding. But the highest about 73 percent of farmers at Bogra performed three times weeding.

\section{Economic profitability of hybrid maize cultivation}

Profitability is one of the major criteria for determination of acceptance of a crop. The production cost, gross return, gross margin, benefit cost ratio, etc. for maize cultivation at different locations are discussed below:

Cost of production: For calculation of cost of production, only the cost of variable inputs like seed, fertilizer, manure, human labour, power tiller, pesticide, irrigation, etc. were considered. The cost included both cash cost and imputed value of farmers own resources used. A perusal of Table 5 revealed that total variable cost of maize cultivation was Tk. 31956 per hectare of which about 33 and 28 percent were for human labour and chemical fertilizer, respectively. About 11 percent of the total cost was incurred for irrigation purpose. It is also calculated that about 70 percent the total cash cost incurred for hired human labour among the cost items. Location-wise, there was no wide variation in the cost of maize cultivation per hectare.

Table 5. Per hectare production cost of hybrid maize cultivation.

\begin{tabular}{|c|c|c|c|c|c|}
\hline \multirow{2}{*}{ Cost item } & \multicolumn{5}{|c|}{ Cost per hectare in Taka } \\
\hline & Rangpur & Dinajpur & Bogra & Kushtia & All areas \\
\hline \multicolumn{6}{|l|}{ Human labour: } \\
\hline Family & 3126(10.01) & 3911(12.20) & 3689(11.38) & 2205 (6.86) & 3233(10.16) \\
\hline Hired & $6314(20.23)$ & 8748 (27.29) & $6851(121.13)$ & $7553(23.50)$ & 7366 (23.05) \\
\hline Total & $9440(30.24)$ & 12659 (39.49) & $10540(32.51)$ & $9758(30.36)$ & 10599 (33.17) \\
\hline land preparation cost: & $2562(8.21)$ & $2614(8.16)$ & $2586(7.97)$ & $3360(10.45)$ & $2781(8.70)$ \\
\hline Seed cost & 3203 (10.26) & $3180(9.92)$ & $3109(9.60)$ & $2611(8.12)$ & $3026(9.47)$ \\
\hline Fertilizer & $9276(29.72)$ & $6982(21.78)$ & 9654 (29.77) & 9574 (29.79) & $8871(27.76)$ \\
\hline \multicolumn{6}{|l|}{ Manure: } \\
\hline Owned & $1470(4.71)$ & $930(2.90)$ & $890(2.71)$ & $594(1.85)$ & $971(3.04)$ \\
\hline Purchased & $475(1.52)$ & 623 (1.94) & $463(1.43)$ & $252(0.78)$ & $453(1.42)$ \\
\hline Total & $1945(6.23)$ & $1553(4.84)$ & $1353(4.17)$ & $846(2.63)$ & $1424(4.46)$ \\
\hline Irrigation cost & 3330 (10.67) & 3812 (11.89) & $2978(9.18)$ & 3897 (12.13) & 3504 (10.97) \\
\hline Insecticide cost & $469(1.50)$ & $220(0.67)$ & 1055 (3.25) & $945(2.94)$ & $672(2.10)$ \\
\hline Shelling cost & $988(3.16)$ & $1033(3.22)$ & $1150(3.55)$ & $1146(3.56)$ & 1079 (3.37) \\
\hline Total variable cost: & $31213(100)$ & $32053(100)$ & $32425(100)$ & $32137(100)$ & $31956(100)$ \\
\hline
\end{tabular}

Bracketed figures indicates percentage 
Return from maize cultivation: Return per hectare of maize cultivation in different locations is shown in Table 6. it is conspicuous from the Table that the average yield of maize per hectare was $7748 \mathrm{~kg}$. The average yield was found higher in Dinajpur. The farmers in Dinajpur sold their produce just after harvest without sun drying. In Bogra and Rangpur farmers sold maize after one on two sun drying the maize cobb. But the farmers in Kushtia sold maize after complete sun drying. That is why, the price of maize was found the highest in Kushtia and the lowest in Dinajpur. However, even then the average yield of the sample farmers was found lower than the demonstration yield. However, the per hectare gross return was found higher in Bogra. Although the yield was lower in Bogra than that of Dinajpur, but the gross return was higher in Bogra because of higher price in Bogra. The average price of grain was Tk. 7.60 per kilogram. The average gross margin was observed to be $\mathrm{Tk}$. 28456 on total variable cost basis. The gross margin was also found higher in Bogra mainly for higher price of grain yield. But in spite of lower yield in Kushtia, gross margin was lower. On the average, benefit cost ratio was found to be Tk. 1.89. It indicated that for every one taka investment, the farmer will get Tk. 1.89. The cost per kilogram of maize cultivation was Tk. 4.12. And return from one kilogram of maize production was calculated as Tk. 7.80 .

Table 6. Return per hectare of maize cultivation in the survey areas.

\begin{tabular}{l|l|l|l|l|l}
\hline \multirow{2}{*}{ litem } & \multicolumn{5}{c}{ Cost per hectare in Taka } \\
\cline { 2 - 6 } & Rangpur & Dinajpur & Bogra & Kushtia & All area \\
\hline Yield (kg/ha) & 7411 & 9385 & 7642 & 6553 & 7748 \\
Yield (Tk/ha) & 57454 & 59937 & 60295 & 55504 & 58889 \\
By-product (Tk/ha) & 1383 & 1426 & 1565 & 1716 & 1523 \\
Gross return (Tk/ha) & 58828 & 61362 & 61860 & 57220 & 60412 \\
Total variable cost (Tk/ha) & 31216 & 32053 & 32425 & 32137 & 31956 \\
Gross margin & 27612 & 29309 & 29435 & 25083 & 28456 \\
Benefit cost ratio & 1.88 & 1.91 & 1.91 & 1.78 & 1.89 \\
Cost per kg & 4.21 & 3.42 & 4.24 & 4.90 & 4.12 \\
Return per kg & 7.94 & 6.54 & 8.09 & 8.73 & 7.80 \\
\hline
\end{tabular}

\section{Factors affecting production of hybrid maize}

For producing maize, different variables, such as human labour, land preparation, irrigation, TSP, MP, zinc, gypsum, borax, manure etc. were employed by the sample farmers. Estimated values of co-efficient and related statistics of CobbDouglas production function is presented in Table 7. The result showed that most of the co-efficients had positive sign. However, the co-efficient for human labour $\left(\mathrm{X}_{1}\right)$, land preparation $\left(\mathrm{X}_{2}\right)$, and borax $\left(\mathrm{X}_{9}\right)$ were found to be positively significant at $1 \%$ level which indicated that $1 \%$ increase in human labour, land 
preparation, and borax with other factor remaining constant would increase the gross return by $0.431,0.369$, and 0.292 percent, respectively. The co-efficient for TSP $\left(\mathrm{X}_{5}\right)$ and manure $\left(\mathrm{X}_{10}\right)$ were negatively significant at $5 \%$ and $1 \%$ level respectively. The negative coefficient of TSP and manure for maize might be for inefficient use of these inputs. Irrigation $\left(\mathrm{X}_{3}\right)$ was found to be significant at $10 \%$ level. This means, there is opportunity to increase gross return by using more irrigation keeping other factors constant. However, the magnitudes of the coefficient imply that human labour, land preparation, irrigation, urea, and borax have considerable effect on gross return for maize cultivation..

The fitted Cobb-Douglas production function was found to be valid as indicated by F-value and R-square. The co-efficient of multiple determinations, $\mathrm{R}^{2}$, was 0.509 which indicate that the explanatory variables included in the model explained $51 \%$ of the variation in maize production. The F-value of the equation is significant at $1 \%$ level of probability implying that the variation depends mainly upon the explanatory variables included in the model.

Table 7. Estimated value of coefficient and related statistics of Cobb-Douglas production model.

\begin{tabular}{|c|c|c|}
\hline Explanatory variables & Co-efficient & t- values \\
\hline Intercept & 5.865 & 7.887 \\
\hline Human labour $\left(\mathrm{X}_{1}\right)$ & $\begin{array}{l}0.431^{*} \\
(0.051)\end{array}$ & 5.650 \\
\hline Land Preparation Cost $\left(\mathrm{X}_{2}\right)$ & $\begin{array}{l}0.369 * \\
(0.066)\end{array}$ & 4.404 \\
\hline Irrigation $\left(\mathrm{X}_{3}\right)$ & $\begin{array}{l}0.214 * * * \\
(0.036)\end{array}$ & 2.760 \\
\hline Urea $\left(\mathrm{X}_{4}\right)$ & $\begin{array}{l}0.256^{* *} \\
(0.003)\end{array}$ & 3.196 \\
\hline $\operatorname{TSP}\left(\mathrm{X}_{5}\right)$ & $\begin{array}{c}-0.194 * * \\
(0.030)\end{array}$ & -2.319 \\
\hline $\operatorname{MP}\left(\mathrm{X}_{6}\right)$ & $\begin{array}{l}0.189 \\
(0.014)\end{array}$ & 1.612 \\
\hline $\operatorname{Zinc}\left(\mathrm{X}_{7}\right)$ & $\begin{array}{l}0.009 \\
(0.012)\end{array}$ & 0.075 \\
\hline Gypsum $\left(\mathrm{X}_{8}\right)$ & $\begin{array}{l}0.006 \\
(0.004)\end{array}$ & 0.067 \\
\hline Borax $\left(\mathrm{X}_{9}\right)$ & $\begin{array}{l}0.292 * \\
(0.004)\end{array}$ & 3.607 \\
\hline Manure $\left(\mathrm{X}_{10}\right)$ & $\begin{array}{l}-0.357 * \\
(0.004)\end{array}$ & -3.883 \\
\hline $\mathrm{R}^{2}$ & 0.509 & \\
\hline $\mathrm{F}$ & 10.048 & \\
\hline
\end{tabular}

Figures in the brackets are standard errors of the regression coefficient

* Significant at $1 \%$ level, ${ }^{* *}$ Significant at $5 \%$ level,*** Significant at $10 \%$ level 


\section{Constraints}

Although hybrid maize was observed to be a profitable crop, there exist lots of constraints to its higher production. To identify constraints, farmers were asked a number of questions. Thereafter, the constraints were edited and summarized to arrive at only a few problems.

The constraints were ranked according to the descending order of frequencies based on the priority of the problems. The 1st ranked constraint to maize production was timely non-availability of seed opined by $87 \%$ farmers followed by high price of fertilizer by $78 \%$ of farmers, while low price of yield, high price of seed, high cost of irrigation were opined as $3^{\text {rd }}, 4^{\text {th }} \& 5^{\text {th }}$ ranked problem is all the areas, respectively (Table 8).

Table 8. Constraints to maize cultivation in the survey areas.

\begin{tabular}{|c|c|c|c|c|c|c|c|c|c|c|}
\hline \multirow{3}{*}{ Constraints } & \multicolumn{10}{|c|}{$\%$ of respondents } \\
\hline & \multicolumn{2}{|c|}{ Rangpur } & \multicolumn{2}{|c|}{ Dinajpur } & \multicolumn{2}{|c|}{ Bogra } & \multicolumn{2}{|c|}{ Kushtia } & \multicolumn{2}{|c|}{ All areas } \\
\hline & $\%$ & Rank & $\%$ & Rank & $\%$ & Rank & $\%$ & Rank & $\%$ & Rank \\
\hline High price of seed & 58 & 4 & 60 & 4 & 65 & 4 & 55 & 4 & 60 & 4 \\
\hline $\begin{array}{l}\text { Timely non-availability } \\
\text { of seed }\end{array}$ & 84 & 1 & 89 & 1 & 92 & 1 & 81 & 1 & 87 & 1 \\
\hline Low price of product & 65 & 3 & 69 & 3 & 73 & 3 & 61 & 3 & 67 & 3 \\
\hline $\begin{array}{l}\text { Damage by fox, dog } \\
\text { and parrot }\end{array}$ & 38 & 7 & 41 & 7 & 45 & 7 & 35 & 7 & 40 & 7 \\
\hline High price of fertilizer & 74 & 2 & 78 & 2 & 85 & 2 & 73 & 2 & 78 & 2 \\
\hline $\begin{array}{l}\text { Scarcity of human } \\
\text { labour }\end{array}$ & 43 & 6 & 47 & 6 & 57 & 6 & 40 & 6 & 45 & 6 \\
\hline High cost of irrigation & 51 & 5 & 55 & 5 & 57 & 5 & 48 & 5 & 53 & 5 \\
\hline
\end{tabular}

\section{Farmers' attitudes towards maize cultivation}

Almost all the farmers in the survey areas reported that they will increase maize area in the next season. When asked about the intention to grow maize in future, 85 percent farmers reported that higher yield and income encouraged them for continuing maize cultivation. While 73 percent farmers in all the areas reported that they will grow maize as it is easy to grow.

\section{Conclusions}

Hybrid maize provided high return to investment. This crop is gaining popularity in the country very quickly due to its high yield potential. Appropriate level of input use and time of operation is important for achieving higher yield and profits, but the technology employed by the farmers were not at the level of 
recommendation. However, seed rate used by the farmers was almost similar to the recommended rate. Although hybrid maize is a profitable crop, but it is very cash cost incentive crop and thereby high cash involvement may restricted maize area expansion. A good opinion came out from the sample farmers in the study areas that higher yield and income encouraged them for continuing maize cultivation.

\section{Recommendations}

Traditional cultural practices are being followed by the farmers so, it is necessary to provide information regarding proper time of sowing, seed rate, fertilizer dose, etc. to the farmers. It may be difficult to cultivate this crop for the poor/small farmers as it requires high amount of cash. Thus, emphasis can be given to reduce cash cost through input subsidy. In other way, capital may be supplemented to the poor/small farmers for hybrid maize cultivation through credit giving agencies with low interest rate. The DAE and other related institutions should made hybrid seed available in time to the farmers as seed played a significant role on yield.

\section{References}

Mohiuddin, Md. 2003. Efficiency and sustainability of maize cultivation in an area of Bangladesh, Unpublished Masters Degree Thesis, BAU, Mymensingh.

Krishi Diary. 2006 Agricultural information Service, Department of Agricultural Extension, Khamarbari, Farmgate, Dhaka.

Report of Household Income and Expenditure Survey. 2005. Bangladesh Bureau of Statistics, Planning Division, Ministry of Planning, Government of the People's Republic of Bangladesh.

BBS. 2003. Yearbook of Agricultural Statistics of Bangladesh, Bangladesh Bureau of Statistics, Ministry of Planning, Government of the People's Republic of Bangladesh, Dhaka.

BBS. 2006. Yearbook of Agricultural Statistics of Bangladesh. Bangladesh Bureau of Statistics, Ministry of Planning, Government of the People's Republic of Bangladesh, Dhaka. 